\title{
Use of question teaching method in the teaching of ideological and political theory course in universities
}

\author{
Liying Yin \\ Jilin Agricultural University Changchun 130118 China
}

\begin{abstract}
Question teaching method is to make the student problem consciousness and innovative thinking of a kind of teaching method. Use of question teaching method in the ideological and political theory course teaching, is beneficial to promote the all-round development of students, to improve teachers' teaching level, to improve teaching effectiveness. Therefore, in the use of question teaching method in ideological and political theory teaching, must pay attention to ask questions, analyze and solve problems.
\end{abstract}

Keywords: Ideological and political theory course; Question teaching method; Using.

\section{Introduction}

Ideological and political theory course is the required courses of the college students' ideological and political education, emphasis the unification of cognition, emotion, and active. But because of the characteristic of the ideological and political theory course abstraction, combined with the traditional teaching model of "cramming education", it is difficult to stimulate students' learning enthusiasm, it is difficult to make students understand the teaching content, teaching effectiveness to be improved. Therefore, how to improve the teaching effectiveness has become the primary problem of ideological and political theory course teaching. Use of question teaching method in the ideological and political theory course teaching, combining the thought and the reality of college students, guide students to think about problems, analyze and solve problems, is the effective ways to improve the university thought politics theory class teaching effectiveness.

\section{The connotation of question teaching method}

Question teaching method is a kind of teaching methods that make students have problem consciousness and innovative thinking, which is teacher according to students' cognitive law, according to the requirements of the teaching content, present the knowledge of teaching material in the form of problems in front of the students, guide students to combine their own life actual or have learned the theory of knowledge discovery and put forward the question, so that students in the thinking activities of thinking, discussion, analysis and solve the problem, grasp the corresponding knowledge, developing intelligence, cultivating ability, especially in training students' ability to find and solve problems, reflect the intrinsic logical relation of ask questions, analyze and solve problems. By their nature, question teaching method is a kind of teaching methods that obeys the law of human thinking and cognitive science, which is the teaching methods, taking problem as the core, through the interaction and communication between students and teachers to realize the goal of teaching and contents of teaching, possess the characteristics of the systematic, exploratory and creative.

3. The great significance of using question teaching method in the teaching of ideological and political theory course in universities

3.1 The application method of teaching in colleges and universities thought politics theory class teaching, promote students' all-round development

In general, there are explore ideas if there are problems, to arouse people's desire, to promote the development of creative thinking, make it easy to study and solve, eventually spark of thinking. The question put forward depends on the cultivation of problem consciousness, the cultivation of problem 
consciousness is not only beneficial to encourage students to think and solve problems, but also develop the students' study consciousness in the subconscious.

The characteristics of the ideological and political theory class is to carry out "students first" the education idea, linking theory with practice, the purpose is to improve the students' ability of analyzing and solving problems. Therefore, the problem teaching method in the application of ideological and political theory course, emphasizing students' main body function, change the state of the students passively accept knowledge, to cultivate students to develop a kind of problem consciousness, forming a kind of habit of exploring issues, in the process of making the students to ask questions and to solve problems, can enjoy the happiness of finding problems, you can also experience the pleasure of success, inspired to continue learning motivation, improve the learning efficiency of ideological and political theory course; Fully mobilize students' language competence, analysis, induction ability, innovation ability, the unity cooperation ability, improve the quality of college students.

\subsection{The use of question teaching method in college ideological and political theory course teaching, to improve teachers' teaching level}

"There will be a master of ancient scholars, teachers, so all trained to reassure also." In the traditional concept of education, the knowledge teachers offered is the truth, and fewer doubt. But in "students first" concept of education, the relationship between teachers and students are equal, democratic and open, the authority of the role of knowledge teacher, the masters of the classroom turned into a student guide, organizer and promoter of learning. As the saying goes, to do a good job, must sharpen the device at first, whether the affection of question teaching is good or not, mainly influenced by such factors as the teachers' knowledge reserve, teaching art, work experience and the designing, controlling, and expanding to problems. This requires that teachers must have a good knowledge background and the wonderful ability to manage knowledge. however, no one is perfect, as the ideological and political theory course teacher, using the questions teaching method in college ideological and political theory course teaching, to fully understand the students' physical and mental development rule and law of thinking, teaching meanwhile learning, enriching the theory of knowledge, timely understanding of current events and political dynamics. Knowledge and problems of the teaching material, the experience and researching results of predecessors, by a new form and appearance, presented in front of students, to mobilize students' initiative, and improve the teaching level.

\subsection{The use of question teaching method in college ideological and political theory course teaching, improve teaching effectiveness}

Ideological and political theory course is the main channel and position in the ideological and political education of college students, is a compulsory course for college students, its basic task is to pass on college students systematic marxist theory education and ideological and political education, help students establish correct world outlook, the outlook on life and values, cultivating the builders and successors of socialism. In the ideological and political theory class teaching by applying the method of problem, is an effective way of teaching effectiveness increases. In the process of teaching, the teacher put forward a question with certain depth of thinking, in arousing students' learning interest and desire to explore, on the basis of guiding students to think deeply and discuss, attracting students to participate actively in classroom activities; At the same time, on the basis of teachers follow the basic laws in the teaching and respect students' personality characteristics, the teaching content would be present relatively complete through the problem, and linked with the real life of college students, in the interaction between teachers and students, interactive discussion, each airs his own opinions, teaching is learning, create a harmonious and democratic classroom atmosphere, so as to help students understand and internalization theory knowledge better, meanwhile improve the teaching effectiveness of ideological and political lesson. 


\section{The problems in the ideological and political theory course teaching implementation of teaching should be paid attention to}

No constant learning method, wisely in the adaptive way. Implementing the questions teaching method in the ideological and political theory teaching, practical. But putting forward questions, analyzing and solving problems must be paid attention to.

\subsection{Ask questions, stimulate students interest}

Interest is the best teacher. Students' interest in learning is one of the standards for testing the teaching effect. Due to the strong theoretical of the ideological and political theory, and abstractness of the concept, students susceptible to boring, difficult to achieve good teaching effect. Therefore, use of question teaching method, based on the core content of each chapter of five courses of ideological and political theory class. Arousing students' learning interest by the question posed. In the process of teaching, putting forward the problem should be combined with the actual, creating problem situation, arouse the enthusiasm of college students' learning and using situation. Problem situation creation methods are numerous , mainly include: (1) the life habit problem situation, which is finding the relatively familiar with the content of students' life when teaching, making the starting point of the teaching is the actual starting point of that students assimilating knowledge; (2) the obstacle problem situation, it is on the basis of "students' original knowledge reserves and consciously to let the students into a new dilemma, to form a new cognitive conflict, so as to arouse students' thirst for new knowledge and to explore a kind of problem situation", by challenging questions to stimulate students' interest in learning; (3) exploratory problem situation, that is, giving students background materials, leading to new problems by reading materials, it can inspire students' thirst for new knowledge.

\subsection{To analyze problems, active students thinking}

Xingzhi Tao once proposed "six big liberation". Namely the liberation of the students' brain, hands, mouth, eyes, time and space, to liberate the students' creativity. Therefore, in the ideological and political lesson teaching, on the basis of practicing, asking questions, arousing the students' interest and enthusiasm. We should encourage students to dare to think, to mobilize student thinking fully and expand students' thinking space. Give full play to the students' creativity, the students will bring problems and according to their own experience to understand the problem, thinking and analysing from different angles. But inseparable from the theory to analyze problems, it needs analysis and research to explore the inherent law of general guiding significance from the different problem situation in the teaching process, it deduces the general principles and theories. Only through theory, make the students master the theoretical knowledge, and then using the theory to analysis their concerns and doubts, to make analysing the problem objectively and thoroughly.

\subsection{To solve the problem and improve students' ability}

Ideological and political theory course teaching for achieving the goal of Marxism theory in college students' mind, it is rely on solving the problem, Combining theoretical knowledge and practical problems, Guiding students to set up the correct position consciousness and problem consciousness, Improving ability to distinguish right and wrong. The wrong thoughts, ideas and methods in students' brain will be replaced by scientific world outlook and methodology, forming scientific world outlook, the outlook on life and values. It needs, in the teaching process, teachers' guiding and encouraging, step by step, avoiding blindly trial and error, gradually cultivate students' consciousness and habits of solving problems on their initiative, encouraging the growth of students theoretical knowledge and ability.

\section{Summary}

Ideological and political theory course is the required courses of the college students' ideological and political education, emphasis the unification of cognition, emotion, active. But because of the characteristic of the ideological and political theory course abstraction, combined with the traditional teaching model of "cramming education", it is difficult to stimulate students' learning enthusiasm, it is 
difficult to make students understand the teaching content, teaching effectiveness to be improved. Therefore, use of question teaching method in the ideological and political theory course teaching, combining the thought and the reality of college students, guide students to think about problems, analyze and solve problems, is the effective ways to improve the university thought politics theory class teaching effectiveness.

\section{References}

[1] Wenge Liu. The effectiveness between the problem teaching with the teaching of ideological and political theory [J]. Journal of capital normal university (Social science edition), 2012, (05).

[2] Kunxiong Tang, Jinhe Li. Three questions of the teaching with problem consciousness in the ideological and political theory course [J]. Ideological and theoretical education, 2012, (12). 